\title{
Cynicism and the Collapse of Multilateralism
}

\author{
Mahbi Maulaya ${ }^{1}$ \\ Department of International Relations ${ }^{1}$ \\ Universitas Muhammadiyah Yogyakarta ${ }^{1}$ \\ Bantul, Special Region of Yogyakarta, Indonesia ${ }^{1}$ \\ mahbi.m.isip18@mail.umy.ac.id ${ }^{1}$
}

\begin{abstract}
Abstrak
Masyarakat internasional saat ini menyaksikan kemanjuran multilateralisme yang menurun dan kondisinya yang sangat rapuh. Beberapa negara mulai merusak jari-jari pada roda berjalannya traktat, perjanjian, organisasi, institusi, dan perwujudan multilateralisme lainnya. Keadaan ini mengarahkan kepada munculnya spekulasi "Keruntuhan Multilateralisme" di dalam banyak literatur hubungan internasional. Studi ini adalah sebuah upaya eksplorasi untuk menyediakan penjelasan konkrit alasan runtuhnya multilateralisme. Tulisan ini berpendapat bahwasanya sinisime yang tumbuh di antara hubungan aktor-aktor internasional menjadi alasan keruntuhan multilateralisme. Ada dua tipe sinisime yang ditemukan, 'sinisime sebagai pemicu' dan 'sinisime sebagai samaran'. Perbedaan di antara keduanya sangat tipis. Sinisime sebagai pemicu dapat terlacak dimana pengunduran diri negara bersangkutan dari multilateralisme adalah semata-mata karena rasa tidak percaya. Di sisi lain, sinisime sebagai samaran terjadi ketika suatu negara mengutarakan tuduhan sinisime kepada multilateralisme untuk menjustifikasi aksi pengunduran dirinya dan mengalihkan perhatian dunia dari kepentingan tersembunyi yang dimilikinya. Karena studi ini memerlukan penafsiran yang dalam dan spesifik, penggunaan metode kualitatif dipertimbangkan efektif. Studi ini menerapkan dua kerangka pemikiran, yakni sinisime dan multilateralisme.
\end{abstract}

\section{Kata Kunci: Multilateralisme, Keruntuhan, Sinisime, Rasa Tidak Percaya, Kepentingan Bersama}

\begin{abstract}
International society is now witnessing the declining efficacy and extremely fragile condition of multilateralism. Several states started to impair the spokes on the wheel of international treaties, agreements, organizations, institutions, and other multilateralism-related vehicles. This circumstance led to the speculation of "Multilateralism Collapse" within the growing body of International Relations literature. This study is an exploratory attempt to explain the reason why multilateralism is failing. The spawned-argument is that the burgeoning cynicism among the relation of international actors served to be the reason of multilateralism free fall. Two types of cynicism have been identified; the 'cynicism as a trigger' and 'cynicism as a guise'. The difference between the two characterizations is razor-thin. 'Cynicism as a trigger' tracked whereby a sense of distrust causes the relevant state to withdraw from multilateralism manifestation. On the other hand, 'cynicism as a guise' happens when a state express cynical accusation to multilateralism in order to justify its resignation and distract world's attention from its hidden interest. Since this study requires
\end{abstract}


a specific and in-depth interpretation on sets of event and data, the utilization of qualitative method was considered applicable. This study applied two theoretical frameworks, namely cynicism and multilateralism.

\section{Keywords: Multilateralism, Collapse, Cynicism, Distrust, Common Interest}

\section{Introduction}

Multilateralism is manifested by the existence of world treaties or agreements, international organizations and institutions, international conferences, summit meetings, and other activities involving three or more states which their interest are, not entirely, but in certain principles, in conformity. These are becoming the arena for assembling a various number of states which their desires, aims, and maneuver on the basis of harmonization. Liberal institutionalists believe that relations between states able to, or in fact should be, coordinated, standardized, and formalized in multilateral manner; international regime and institution. Those mechanisms would establish, implement, then administer sets of rules which supervise the behavior of states in particular policy scopes. The multilateral regime and institutional cooperation granted more quality of regularity and predictability. It performs the role of reassuring cooperative attitudes among states, supervising obligation fulfillment, and admonishing or even penalize the defectors of consensus-established norms (Burchill, 2005). Moreover, the multilateral system is a sovereignty and democracy enhancing mechanism due to it polices the distributive excesses of the modern welfare states by encouraging governments to adhere specific rules based on the norm of non-discrimination (Raustiala, 2000). On this groundwork, Miles Kahler's considered the 'international structure of the many' as the formula for maintaining peace and security of the international community (Kahler, 1992).

Although multilateralism presence had started before the end of World War II (by the existence of Treaty of Westphalia in 1648, Central Commission for Navigation on the Rhine in 1815 and League of Nations in 1920), the very significant importance of multilateralism was surging forward after the end of World War II. As the victor, the United States reintroduced multilateralism in terms of specific, more regulated principles compared to the multilateralism in early of $17^{\text {th }}$ century. As the liberal form world began to widely accepted and the organizing principles of multilateralism has been formalized, multilateralism's manifestation has been massive in number. It was manifested in the proliferation of multinational conferences on a bewildering variety of themes and an increasing number of multilateral intergovernmental organizations from fewer than 100 in 1945 to about 200 by 1960 and over 600 by 1980 (Jacobson, 1984, in Keohane, 1990).

Multilateralism, unfortunately, is facing its final day. In recent years, multilateralism is in its agony to survive, posing a severe risk to the future 
prosperity of international society (Kingo \& Mather, 2019). The declining efficacy of multilateralism is demonstrated by great deal of problems across the range of multilateralism norms and environment. Examples of this include; the failure of Iran Nuclear Deal, U.S. withdrawal from Paris Climate Change Agreement, Arms Trade Treaty (ATT), United Nations Human Rights Council (UNHRC), United Kingdom intention to leave the European Union, questioning of International Criminal Court (ICC) by some prominent African countries, China's arbitrariness to 'pick and choose' the adherence upon UNCLOS and others. Moreover, a significant number of literatures has written by scholars and observers, which most of the proposed hypotheses in their writings are parallel, e.g., Recent Threats to Multilateralism by Johannes Linn, Multilateralism in Freefall by Richard Gowan, Multilateralism under threat by Marcelo Rech, and Multilateralism under challenge? By Edward Newman, Ramesh Thakur, and John Tirman, and other relevant works. These high-quality literatures could portray the severity of is the collapse of multilateralism.

Several opinions has proposed by international political observers to explain why this phenomenon occurs. Richard Gowan's opinion is worthy to be mentioned. He argues that the U.S., which plays a strategic and important role as the de facto guarantor of the international order, is led by an incumbent president who question the value of international institutions often on a weekly basis. The unpredictability and aggressiveness of Donald Trump-led administration in multilateral activities has drawn international society's awareness to suggest that multilateralism should now be in its free-fall (Gowan, 2018). Another argument is put forward by Louis Charbonneau. Besides the unpredictability of U.S. President Donald Trump, Charbonneau (2019) also believes that the threats to multilateralism rise since other countries trying to weaken international organizations and make them docile. He also believes that the leaders of multilateral institutions compromise their mandates in the name of protecting them.

This study asks "what is the fundamental, general, cause behind the collapse of multilateralism?". This study endorses a slightly different answer as the the literature suggests, arguing that the growing cynicism among international actors is the reason why multilateralism in crisis.

This study is structured as follows. First, since multilateralism and cynicism both serve the basis concept to this study, the provision of a comprehensive elaboration to the two conceptual frameworks, multilateralism, and cynicism, is essential to be paid of attention. This study extracts explicit definitions of both concepts, which concluded from their historical background and the debate among scholars in defining them. The subsequent section is the discussion. This study addresses three differing explanations, namely the glory of multilateralism, the collapse of multilateralism, and tracking the cynicism amid multilateralism fall. At the end of this study, a conclusion to summarize the results and points is given. 


\section{Conceptual Framework}

Multilateralism is the original product of liberalism school of thought which serves a significant contribution in explaining the dynamics of state's relation. In the other side, the term cynicism scarcely utilizes, compared to multilateralism, to analyze the dynamics of multilateralism. In this section, this study would elaborate both concepts in a modest exploration.

\subsection{Multilateralism}

Robert O. Keohane (1990) defines multilateralism as the practice of coordinating national policies in groups of three or more states, through ad hoc arrangements or by means of institution. John G. Ruggie portrays this argument as banal and questionable hypothesis as he said it is disposed to be the nominal definition of multilateralism.

The nominal definition of multilateralism may be useful for some purposes. However, it poses the problem of subsuming institutional forms that traditionally have been viewed as being an expression of bilateralism, not multilateralism. In short, the nominal definition of multilateralism misses the qualitative dimension of the phenomenon that makes it distinct (Ruggie, 1992, pp. 565).

The missing qualitative dimension of multilateralism's definition comes to John G. Ruggie's attention. Hence, he reconstructed multilateralism's meaning and simultaneously combined Keohane's definition,

Multilateralism is an institutional form which coordinates relations among three or more states on the basis of generalized principles of conduct (that is, principles which specify appropriate conduct for a class of actions, without regard to the particularistic interest of the parties or the strategic exigencies that may exist in any specific occurrence) whether or not any specific instance suits their individual likes and dislikes (Ruggie, 1992, pp. 571).

Multilateralism is not only a value or principle, but also a set of mechanism, encouraging the involving parties to establish common goals and collectively commit to attain them by mutual efforts and reciprocal supports. Acknowledgement of other's sovereignty is an obligation for all parties. Any discriminative act erodes the essential norms of equality of multilateralism and therefore it must be abolished. Common interest serves as the basic principle of the existence of multilateralism.

An appealing perspective surfaces on the difference between multilateralism and multilateral diplomacy. The elaboration on it within this study is essential since both concepts possess significant disparity. To this issue, Ryo Oshiba's argument is compelling. Oshiba argues that,

Multilateral diplomacy does not equal to multilateralism. Simply because a forum has been provided for multilateral diplomacy, it does not necessarily follow that all participating countries will share common ideas and principles 
regarding the agenda discussed there. Rather, there are many instances in multilateral diplomacy, where countries openly pursue their respective national interests. This situation could be called multilateral diplomacy without multilateralism (Oshiba, 2013, pp. 3-4).

Multilateral diplomacy is an approach in diplomacy that exploits and utilizes multilateralism platform to achieve the personal interest of relevant states. A state can use multilateral diplomacy as its means to accomplish its self-interest and potentially undermine and discriminate other states. The states who behave so can be mentioned as the "free riders." In this atmosphere, the appearance of this behavior makes multilateral diplomacy deeply ambivalent to multilateralism. Multilateralism, in a broad manner, is expressed an impulse of a practice, an institution, or a believe, which endorse the value of non-discrimination and common interest. In this view, this study opts to use the term "multilateralism" rather than "multilateral diplomacy."

\subsection{Cynicism}

The origins and meaning of "cynicism" remains debated. Two versions of "cynicism" meanings are important starting points. In one description, cynicism was a classical school of Ancient Greek philosophy. A school with its name based on the location where Antisthenes, a Greek philosopher, lived. The place named as Cynosarges, a public gymnasium outside of the city of Athens, reserved for people appraised 'unworthy' to be Athenian citizens (Matsons, cited in Schutijser, 2017).

On the other hand, cynicism is often linked to its etymological proximity of " $\kappa u \dot{\omega} \omega v^{\text {" }}$ (kynos), or dog (Piering, n.d.). The phrase "dog" referred to followers of cynicism in ancient Greece based on four reasons. First, the cynics have a lack of concern about their way of life. They make a cult of indifference and, similarly to dogs, eat and have sexual activity in public, walked barefoot, and slept in tubs and at crossroads. The second reason is that the dog is a shameless animal, and they glorify shamelessness, not as being beneath humility, but as superior to it. The third reason is that the dog is a good squire, and they guard the principles of their philosophy. The fourth reason is that the dog is a discriminating animal that can differ materially between its friends and enemies. So, they do identify as friends those who are suited to their philosophy and accept them generously, while those unfitted, they drive away, like dogs, by barking at them (Dudley, 2011).

Ethics and morality have been explored in the social sciences by studying various individual perceptions, attitudes, and behaviors (Turner \& Valentine, 2001). In this light, cynicism, as one of individual attitudes, has been merged within social science. The term cynicism makes use in the field of psychology. Cook and Medley (1954), in their paper "Proposed hostility and Pharisaic-virtue scales for the MMPI", considered cynicism as a personality variable. In the realm of political studies, Pattyn, Hiel, Dhont, and Onraet (2011) discussed political cynicism in 
their paper "Stripping the Political Cynic: A Psychological Exploration of the Concept of Political Cynicism." Within organizational studies scope, Turner and Valentine (2001) discussed the relation between cynicism and the decisionmaking process of an organization in their works entitled "Cynicism as a Fundamental Dimension of Moral Decision-Making: A Scale Development."

In this study, the terms cynicism will be used to explain the dynamics multilateralism studies. Nowadays, cynicism has a different, perhaps less, negative connotation. In modern era, a cynic is defined as a person who shows a personality or character to disbelieve or mistrust in the sincerity or goodness of human motives and actions and want to express this by jeers and sarcasm; a sneering fault-finder (Dictionary.com, 2020). The contemporary cynic's notion of human nature is outspokenly wrong, as they question the selflessness of any human action. Modern cynics thus seem hardly to believe in other actors. The contemporary cynics' criticism is rooted in an intense distrust of human nature (Pattyn, Hiel, Dhont, \& Onraet, 2011).

In international relations theory, cynicism is perhaps best represented by the classical realist school of thought. At a glance, classical realism would be more receptive to and worked in symbiosis with this study. Yet, it would be bedevilled by a problem. Classical realism, particularly in Hobbesian perspective on human character, believes that humans absolutely are violent and uncooperative in nature. Due to humans are empty of trust to each other, any agreement will be irrational and would not be broached. Therefore, the formulation of cooperative organizations (multilateralism) should not occur in the first place (Clark, 2016). In this study, a different perspective is taken. States that are unit of analysis are the entities that at first believes in cooperation and portrays other states as the trustable partner, thus making multilateralism gain its place. To be clear, the states in this study are those who embrace liberal institutionalist perspective in the beginning. To this extent, classical realism is unable to explain this phenomenon. Moreover, arguing that the rise of classical realism's way of thinking is the main catalyst for the collapse of multilateralism will be appropriate only when multilateralism has entirely receded.

The term "functioning cynicism" may be more appropriate in this study rather than "skepticism". These two words indeed are related to the possession of a sense of doubt. Nevertheless, they both have significant differences in principle. Skeptics are open-minded, and cynics are not. A skeptic is an actor who would evaluate the existing facts and having the intention to seek for the truth. Hence, they have the possibility to shift their negative mind. Otherwise, cynics have already judged and have decided their position to detest something. Any investigative, trustworthy, fact-based information found out that contradicts their beliefs is considered false evidence. If we take into account Popperian ideas of falsification, 'non-falsifiable' is the cornerstone for cynicism' position. This stance makes the cynic propose unfalsifiable claims. Unfalsifiable claims are often faith-based, and not founded on evidence and reason. Thus, it is a way for 
the cynic to leave the realm of rational discourse. The cynic does not have commitment, as what Eugene F. Bales (2008) said, "to the need for an intellectual or philosophical framework...and (they) frequently ended with parodies of philosophers and their pretensions". If a cynic has an argument, there will be nothing count against it. As how a true believers' have the propositions that 'God is exists'- for many true believers there is no conceivable vocabulary that would count against the proposition (Flanagan, 1991, p. 75).

The shadow of cynicism has been strongly entrenched within most cases of states withdrawal from multilateralism. The states leaving multilateralism are bluntly being cynical and questioning the existing multilateralism; therefore, they often express this tendency by jeers and sarcasm. Capturing this view, this study identifies the cynical background of states in their departure from multilateralism.

\section{Discussion}

\subsection{The Glory of Multilateralism}

When a well-designed canvas falls to the floor, we can deduce that it was firmly attached to a perpendicular wall. When something is experiencing a period of destruction, it can be concluded that it had previously experienced an era of glory. This structured-pattern of life also applies to multilateralism. When multilateralism is in its collapse phase, all of us must deal with the fact that multilateralism indeed had its glory in the past.

During the Cold War, multilateralism had a significant role in preventing or resolving conflicts in about $25 \%$ of conflicts around the globe (Aviel, 1999). In international economics, multilateralism has been the main player for the huge economic success of the past half century (Krueger, 2011). Multilateral institutions such as World Trade Organization, International Telecommunications Union, and International Monetary Fund, combined with the competitive spread of standardized systems and technologies of production, have significantly increased the flexibility and security with which goods, capital, and knowledge flow across national boundaries, transforming more integrated international economy (Sjolander, 1996).

A huge number of new emerging and independent states were assisted by multilateral means in their nation-building and in gaining international recognition. William Maley (2018, as cited in Stephanie, 2018) postulated that multilateralism serves various functions such as coalition building, issue prioritization, and agenda-setting. These means can support small power states in their struggle for achieving interests, such asgaining full sovereignty and international recognition. Major multilateral institutions, such as United Nations, provide forums in which less powerful states can engage with representatives from many states at once by relatively low cost. 
Multilateralism is related to another principle that became a root of decolonization process after 1945. In its formal institutional design, at least, most postwar multilateral institutions incorporated significant mechanisms to provide power for states that were not great powers, and could not aspire to be, to escapecolonization. Multilateralism has provided indirect and invisible assistance for the colonialist's victim states to gain their sovereignty (Kahler, 1992).

Multilateralism also plays a vital role in the era of globalization. In the $21^{\text {st }}$ century, the changes of current global economic, political, and security situation due to globalization requires countries to open their hand in cooperating with others (Wibisono, 2006). Furthermore, globalization growths from, among other aspects, development in technology, communications, and economics that make states more interdependent to others (Barkin, 2006). The interdependence among countries demanded them to maintain cordial and peaceful relations with others by an intense communication and collaboration. In the process of cooperation, multilateralism is manifested as a bridge.

Emerging issues, occasionally dubbed "non-traditional issues", such as environmental issues, nuclear weapon proliferation, cybercrime security, gender equality, sustainable development, and protection of human rights, have encouraged nations to work together through multilateralism. States have found that it is wise to take greater collective responsibility to overcome aforementioned issues for their mutual good. In this light, multilateralism thus flourished rapidly since it gives a good role to facilitate those states' join efforts.

\subsection{The Free Fall of Multilateralism}

The good prospect for the sustainability of multilateralism is observed by the quality of states' commitment for it. Manifestations of multilateralism manifestation is producing and distributing the sense of either common purpose or common challenges for the states (Gurria, 2018; Moreland, 2019). When the states try to downplay or abolish those senses, multilateralism would no longer able to shore up for itself. Most importantly, the key element for multilateralism embodiment is state's willingness and approval to join within it. If state starts to feel reluctant to join, or at worst, to leave the multilateralism manifestation, how could multilateralism survive?

Koffi Annan has predicted the fall of multilateralism a decade earlier. In November 2003, the $7^{\text {th }}$ United Nations Secretary-General expressed his concern to the unstable situation of international order,

The past year has shaken the foundation of collective security and undermined confidence in the possibility of collective responses to our common problems and challenges. It has also brought to the foredeep divergences of opinion on the range and nature of the challenges we face and are likely to face in the future (Annan, 2003, in Newman, Thakur, \& Tirman, 2006, p. 1). 
Although his words probably a response to the unstable conditions at that time, whereby many conflicts happened (U.S. invasion on Iraq, war in Darfur, Balochistan conflict, etc.), the statement clearly illustrates his concern in the future stability of the international order.

Antonio Guterres's response to multilateralism failure is the most catching explanation. In September 2018, the $9^{\text {th }}$ United Nations Secretary-General was attending General high-level debate of the UN General Assembly, and he said that,

Our world is suffering from a bad case of 'trust deficit disorder,' and multilateralism is under fire precisely when we need it the most. Trust is at a breaking point (trust in national institutions, trust among nations, trust in the rules-based global order. Within countries, people are losing faith in political establishments; polarization is on the rise, and populism is on the march. Among countries, cooperation is less specific and more difficult. And divisions in the Security Council are stark. Trust in global governance is also fragile, as $21^{\text {st }}$-century challenges outpace $20^{\text {th }}$-century institutions and mindsets (Guterres, 2018, in Multilateralism is under fire, 2018, pp. 1).

Antonio Guterres considered the lack of trust among states becomes the principles barriers for multilateralism. Lack of trust, as Gutteres argues, can cause difficulties to formulate a common interest, which is the main product of multilateralism. If we are discussing a lack of trust and confidence in others, cynicism will play its part.

\subsection{Identifying Cynicism amidst Multilateralism Collapse}

It has been widely acknowledged that the dark clouds on multilateralism's horizon comes from the combination of weakening national political consensus, growing distrust of elites and experts, and rising nationalism, populism, and authoritarian regimes in the national political dimension (Linn, 2018). Donald Trump's successful ascendance to the President's office is now the most real and recent example of nationalism, populism, and unilateralism that led to the questioning of multilateralism (Bacaria, 2017). The slogan, "Make America Great Again", represents nationalist and populist tendencies that have opened the floodgate of unilateral threats towards multilateralism.

The rising sense of nationalism and populism has been generating a high degree of negative thoughts, therefore diminishing the good will of state to perceive multilateralism's goal. Negativity leads to cynicism, making states willing to leave the multilateralism. The dissatisfaction in multilateralism has provoked by the cynicism of a state to the other. In the past five years, many states assumed others (whether it is fellow states or multilateralism body itself) are motivated purely by self-interest and possessing a hidden agenda or bad intention. In consequence, they often make multilateralism body as the target to express their distrust, which commonly manifested by mockery, satire, and made-up accusations. Cynical state actors will determine their behavior immediately 
without questioning and allow themselves to have a fact-based and trustworthy assumption. In a nutshell, states began to act unilaterally towards multilateralism manifestation after cynical assumption reign its sense. This is the stage whereby cynicism of states plays its role as the culprit of multilateralism's collapse.

Several issues need to be addressed to prove this argument. Most of actor's withdrawal from multilateralism is based on cynicism. There are two types of cynicism that has been analyzed, the 'cynicism as a trigger' and 'cynicism as a guise'. 'Cynicism as merely a trigger' is identified when the key reason influencing a state to leave particular multilateralism manifestation only triggered by the sense of distrust to other states or to multilateralism itself. On the other hand, 'cynicism as a guise' is the expression of relevant states to justify its withdrawal action. Its decision for leaving multilateralism is due to ulterior motives, something that the state does not want to address bluntly to international society. It addresses cynical statement towards multilateralism only to secure it faces from resentment (the accusation was intended hoping that the international community blamed the multilateralism instead of the state). The state's resignation from multilateralism is certainly driven by its self-interest. Within the first type of cynicism, the self-interest is not explicitly striking. Whereas the second type, state's self-interest is evident.

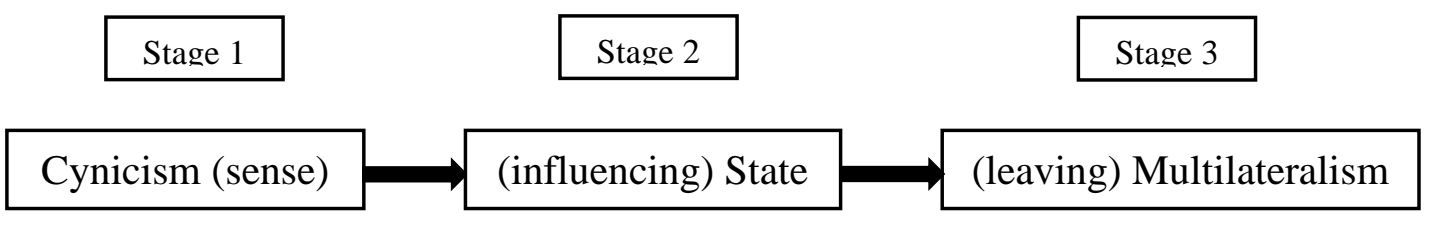

Figure 1. The road of cynicism as a trigger

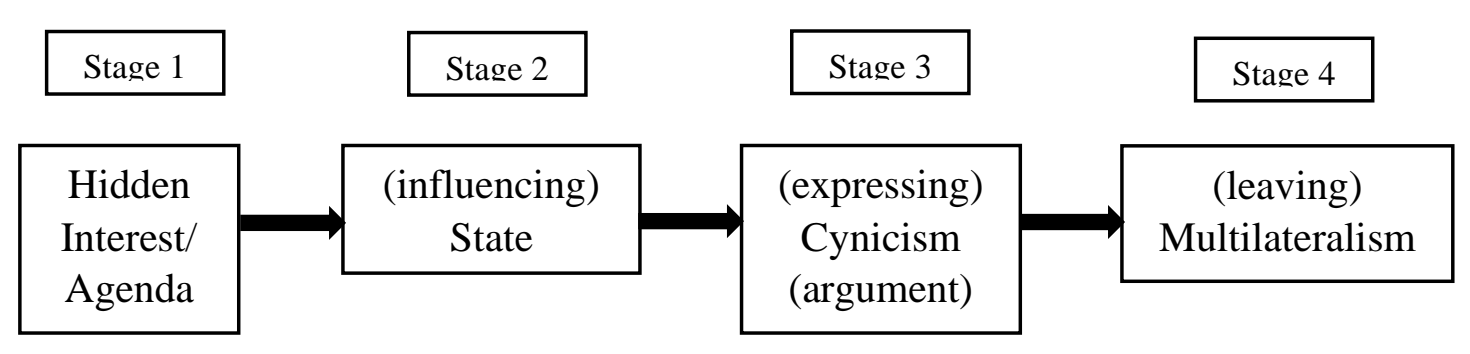

Figure 2. The road of cynicism as a guise 
In this type, the cynical state's decision to withdraw from a multilateralism manifestation is influenced and triggered by a cynical assumption, a distrust towards other actor's involvement in the related multilateralism manifestation. The related state has an exaggerated sense of caution since it believes other actors have specific intentions or ulterior motives to weaken, threaten, its interest. To prove this argument, a set of concrete evidence would be necessary to put. Two cases had happened in recent years which demonstrate this dynamic, viz, the case of U.S. withdrawal from Iran Nuclear Deal and Paris Climate Change Agreement.

The Joint Comprehensive Plan of Action, which also known as the "Iran Nuclear Deal", is an agreement reached by consensus in Vienna, on July 14, 2015, involving Iran and $\mathrm{P} 5+1^{\prime}$ actors and also the European Union. Under the agreement, Iran guaranteed the limitation of its nuclear activities by eliminating medium-enriched uranium stockpile, cutting low-enriched uranium provision, and assuring not to build any new heavy-water facilities of nuclear reactor. Iran also agreed to allow inspectors from International Atomic Energy Agency to supervise its nuclear activities. As a return, the U.S. and allies were in favor for the lifting of crippling economic sanctions to Iran (Iran Nuclear Deal, 2019). This agreement, which required two years of grueling negotiations in tatters, had been successfully eased the tension between the U.S. and Iran, and it was an indication of multilateralism success.

The success of this agreement has already on the edge of fiasco after U.S. announced its withdrawal on May 8, 2018. The U.S. withdrawal from the deal causes the reimbursement of more stringent sanctions on Iran, which already imposed before the deal, and also the reconsideration of a new penalty (Landler, 2018). To respond to the U.S. pullout, Iranian President Hassan Rouhani announced that Iran would decrease some of its commitments and obedience to the 2015 deal (Iran to restart, 2019).

Several reasons underlie the U.S.'s decision to leave the deal. First, the cynical assumption of Trump's administration. In a speech in front of the pro-Israel lobby group American Israel Public Affairs Committee (AIPAC) in March 2016, President Donald Trump argued that the deal was a "disaster, worst deal ever negotiated, and could lead to a nuclear holocaust" (The Wire, 2016). The U.S. believes, convinced by Israel as its closest Middle East Partner, that the non-proliferation deal paves Iran's path to the actual development of nuclear bombs arsenal and the pursuit of regional hegemony (Torbati, 2016). Both U.S. and Israel assumed that lifting economic sanctions would provide a great opportunity for Iran to increase its economy and simultaneously its military budget in which the budget is suspected of being used to develop nuclear weapons and to provide financial support for proxy groups that fueling regional conflict. 
The cynical assumption of U.S. has led to its decision to withdraw from the multilateralism manifestation called as Iran Nuclear Deal. The rising tension between U.S. and Iran has agitated the stability of international order and also strengthen the indication of multilateralism collapse. The negative thinking of U.S. to Iran's motive to join the deal has obviously implied that the cynicism in assumption form serves to be one of the essential factors of multilateralism failure.

The Paris Climate Change Agreement is a treaty drafted in Le Bourget, France and involved the participation of 195 parties. The agreement was signed on April 22, 2016 and came into force on November 4, 2016. The parties, which represent almost $97 \%$ of global greenhouse gas emissions, such as European Union, China, the U.S. (but afterward decide to leave), and India, have acceded to the Agreement (Friedrich et al., 2017; European Council, 2020). Under this agreement, the participants committed to voluntarily reduce their greenhouse emissions in order to fight climate change. Unfortunately, the U.S. as the world's second-biggest emitter of carbondecided to withdraw from the treaty.

Donald Trump announced that the U.S. would withdraw its participation from the world's most comprehensive climate agreement on June 1, 2017. The U.S. began its formal withdrawal by submitting its letter of notification to the SecretaryGeneral on November 4, 2019. The resignation will officially effective one year from the date of notification delivery.

The sense of distrust on other participating states in the Paris Accord triggered the U.S. maneuver to pull out from the treaty. Trump directly judged the Paris Agreement as a means of other countries to undermine his beloved country's economic power. He opined that the treaty might put U.S. at a permanent disadvantage. (Chakraborty, 2017). On 1 June 2017, when President Trump delivered his crucial campaign promise at Rose Garden, he said that:

This agreement is less about the climate and more about other countries, gaining a financial advantage over the United States. The rest of the world applauded when we signed the Paris Agreement for the simple reason that it put our country, the United States of America, which we all love, at a very, very big economic disadvantage (Trump, 2017, in Wolffe, 2017, pp. 1).

Not only considering the climate change issue is a hoax, and humans were not contributed to the climate change condition, but President Donald Trump also accused other countries of disdaining the U.S. after joining the treaty. He declared that "We do not want other leaders and other countries laughing at us anymore, and they will not be." He also added, "The Paris Climate accord is........an agreement that disadvantages the United States to the exclusive benefit of other countries..." (Easley, 2017).

Negatively expecting other actors' stance is the behavior of a cynical actor. Global warming caused by climate change is a convincing fact, and becoming a 
common problem for international society. The participant of the Paris agreement are the actors who intended to put serious effort to overcome the crisis. Protecting the environment for human life sustainability is more important for international actors rather than for weakening the U.S. economic power.

\subsubsection{Cynicism as a Guise}

Cynicism as a guise may be identified when a state released the expression of jeers, sarcasm, and accusation as their fundamental reason to leave the multilateralism manifestations. The state's withdrawal was not provoked by its distrust to other actors, but it merely because it wants to achieve its own hidden interest. The cynical statement serves to be the relevant state's subterfuge to inform the international community about its withdrawal. Simultaneously, the negative statement is intended to strengthen the justification of its action. This argument is particularly striking in the case of African states mistrust to ICC, U.S. resignation from Arms Trade Treaty, and U.S. disengagement from UNHRC.

On February 1, 2017, the African Union (A.U.) proposed a non-binding resolution calling for member states to leave the International Criminal Court (ICC). African countries seemed to be signaling a collective vote of no confidence for the global community's most prominent organization authorized with suppressing the impunity of those responsible for war crimes and crimes against humanity. The A.U. resolution came on the waves of moves by the governments of Burundi and South Africa to withdraw from the ICC (Nantulya, 2017). Although the resolution was not strong enough since it does not have any executive and binding resolution, it raised the possibility of mass walk-out. The exit of African states could be significant, due to a third of the ICC's member countries being African (Jarvi, 2017).

The A.U. resolution began to show its effect when Burundi officially became the first African state to comply with it by leaving the ICC formally on October 27, 2017 (Presse, 2017). Both A.U. and Burundi accused the ICC of undermining state's sovereignty and unfairly targeting only most of Africans states (Igunza, 2017). There were other countries bluntly who have violated human rights and conducted crimes, such as the U.S. in Iraq, Israel in Palestine, and China in Rohingya. Nonetheless, those countries have successfully escaped the scrutiny of ICC. Moreover, A.U. and some of its members are considering the ICC as another instrument of colonization and a means for suppression and domination by western states (Mesele, 2019). Gambia (under Yahya Jameeh administration) expressed its pique by changing the name of International Criminal Court into International Caucasian Court (Kayupa \& Muryantini, 2018).

The argument of A.U. and Burundi to leave ICC, which consist of cynical accusation, become the excuse to justify its decision. They want to encourage international community to believe that the ICC's disorder is the reason for them 
to leave the institution. Yet, they possess a hidden interest behind their controversial decision.

The deficiency of accountability has been an underlying reason for Africa's continued underdevelopment, failed states, and civil wars. In most African states, authoritarian leaders are often more protected than the rights of ordinary citizens, the public interest, and the well-being of the country. Instability in Africa caused by impunity, ordinary citizens' acceptance of African leaders' autocratic behavior, and corruption to stay in power. Since its freedom from colonialism and became self-determinant states, most African state's judiciaries are controlled, suppressed, or manipulated by generally corrupt presidents, leaders, and governing parties. African Court of Justice and Human Rights as the Continental and regional African judicial tribunals, courts and commissions, are often dismissed, ignored, or laughed-off by African leaders. (Gumede, 2018)

The 'bad' background has became the groundwork for the African States to withdraw from ICC. African states have many controversial domestic issues, many of which may be solved with assistance by authoritative third parties. No actor possesses an effective capability to investigate and provide penalties to the problematic African states other than ICC. Hence, if they still serve as a part of ICC, the ICC would still have the authority to interfere in their domestic problems. The interference of ICC is deemed to be problematic for the leaders of African states. The resolution of A.U. related to ICC and Burundi withdrawal are consisting of a self-interest manner and the cynical accusation thus serve as a means to conceal self-interest.

The Arms Trade Treaty (ATT) rules global standards for transfers of conventional arms. It came into force on December 24, 2014. 105 states have ratified the treaty, yet 32 states have signed but not ratified it (Arms Trade Treaty, 2013). The existence of this multilateral treaty sets the first global accord to regulate conventional weapons transfers. The agreement generally seeks to diminish the illicit arms trade, decrease human suffering caused by irresponsible and illegitimate arms transfers, enhance regional security and stability, and advocate transparency and accountability to the member states regarding transfers of conventional arms.

President Trump effectively withdrew the U.S. from the treaty on April 26, 2019. At the annual meeting of the National Riffle Association in Indianapolis, President Trump has said "We will never surrender America's sovereignty to an unelected, unaccountable, global bureaucracy (Chappel, 2019). He also continued, "The United States will be revoking the effect of America's signature from this badly misguided agreement. United Nations will get the notice that we are formally rejecting his treaty (Abramson \& Webb, 2019).

Trump's accusation to the global order was intended to distract the attention of the international community from its self-interest. This treaty obliges the 
participant states to establish and maintain an effective national control system for export, import, transit, and transshipment of conventional arms. Or in other words, the treaty has the authority to interfere the participant states' regulations regarding to conventional arms if the relevant state's national policies do not in line with the treaty. U.S. is the biggest arms exporting states with the total value of exported arms worth $\$ 10.5$ billion in 2018 (Army Technology, 2019). If it becomes the part of this treaty, its arms export to other countries would be dictated, or even controlled by the treaty. Hence, the most rational choice for the U.S. to avoid this unfavorable circumstance is by withdrawing itself from the treaty. To justify its decision, it accused the body which gave birth to the treaty as "an unelected, unaccountable, global bureaucracy."United Nations Human Rights Council (UNHRC) is one of the leading influential multilateral organization responsible for strengthening the promotion, protection, and adherence to human rights around the entire globe. It also owns a big-wheel of authority to deal with human rights violations issues and making recommendations on them.

The U.S. announced its withdrawal from the UNHRC on June 19, 2018. The decision declared by Ambassador Nikki Haley a month after the Human Rights Council accused Israel of excessive use of force on large-scale civilian protests and voted to probe the killing of Palestinian protesters in the Gaza Strip (UN Votes - 2018). Nikki Haley then blamed the body for being hypocrite and selfserving. She said that "We take this step (the withdrawal) because our commitment does not allow us to remain a part of a hypocritical and self-serving organization that makes a mockery of human rights" ('The US withdraws' - 2018).

Israel is the closest, important ally of U.S. At the time when Israel serves the interest of U.S. in the Middle East, the U.S. supports the interest of Israel to the world. The withdrawal from the UNHRC is the manifestation of the U.S. disagreement with the UNHRC'S decision and tendency to interrupt on Israel's sensitive business. One of the most eye-catching and longstanding issues regarding to UNHRC is the council's excessive and exaggerated focus on Israel (Freedman, 2015). It is obvious that Israel commits human rights violations in the Occupied Palestinian Territories. However, since the Council's establishment, those violations on human rights have received more examination and attention than other demonized and pardonless atrocities elsewhere (Freedman, 2018). The cynical accusation of U.S. to the UNHRC merely becomes an excuse to justify its decision. Whereas, the real motive behind its withdrawal was to stand beside Israel when UNHRC's gestures seem annoying. As what Human Rights Watch Director Kenneth Roth said "(US' withdrawal from UNHRC) is a sad reflection of its one-dimensional human-rights policy: defending Israeli abuses from criticism takes precedence above all else" (Wolfe, 2018). Acquiring full status of 'global leader' allowed U.S. to laid down the cornerstone for the construction of postwar international order. Mostly, it was done by the means of multilateralism (Ikenberry, 2003), whereby it has helped the establishment of numerous multilateral organizations, beginning with the League of Nations and the 
International Labor Organization in 1919, and the United Nations in 1945 (Ruggie, 1994). Needless to say, the U.S. was the main backer of multilateralism. Without its support, multilateralism would never been materialized (Benner, 2019). Yet, nowadays U.S. stands in the mirror position, as how Will Moreland implies "the United States scorns a growing number of multilateral institution and norms each day (Moreland, 2019). Since it dominated the cases which has been elaborated above, U.S. is now the main actor for the vandalism of multilateralism, thanks for its cynicism. Multilateralism will need the support of the big players to survive (Dervis, 2018). If a great power such as U.S., the one who helped the multilateralism shore up, lost its faith to favour the multilateralism, questioning the sustainability of multilateralism will come up as a daily discussion for international society.

\section{Conclusion}

The previous discussion makes it clear that most of the actors who retreat from multilateralism are triggered by cynicism, or a sense of distrust to other actors. The cynicism of the relevant states consists of two categorizations, namely 'cynicism as a trigger' and 'cynicism as a guise'. The case of U.S.' withdrawal from Iran Nuclear Deal and Paris Climate Change Agreement can be illustrated as the manifestation of 'cynicism as a trigger'. And the effect of 'cynicism as a guise' was particularly striking in the case of African states mistrust to the ICC, U.S. resignation from Arms Trade Treaty and UNHRC.

The gloomy picture of multilateralism has been painted. Nevertheless, there is no ground for us to perceive the future of multilateralism in a pessimistic manner. Multilateralism is indeed going through a decline. Yet, the phase will not last forever. The potency of multilateralism is observable by looking through its prolificacy in other part of the world. The oft-held Group of Twenty (G20) meetings, the emergence of BRICS as multilateral group of rising powers, the significant development of Shanghai Cooperation Organisation (SCO) in Central Asia, the effectivity of Association of Southeast Asian Nations (ASEAN) to prevent the occurrence of direct conflict in Southeast Asia, the creation of Asian Infrastructure and Investment Bank (AIIB) as a new emerging international financial institution, and others, are the groundworks to suggest that multilateralism has a bright prospect in bridging the conduct of state's relation in the future. Since this study has found cynicism as the root of multilateralism's free-fall, the establishment of common interest and the eradication of distrust between the relations of states in international order can be the cure for multilateralism. 


\section{Acknowledgement}

The author would like to thank to Dr. Ahmad Sahide, Ali Maksum, Ph.D., Zain Maulana, Ph.D., fellow research assistants at Centre for Development and International Studies (CEDIS), and colleagues at Komunitas Belajar Menulis (KBM).

\section{References}

\section{Books}

Aviel, Fagot, JoAnn. (1999). The Evolution of Multilateral Diplomacy. In James P. Muldoon Jr, Joann Fagot Aviel, Richard Reitano and Earl Sullivan (Eds.), Multilateral Diplomacy and the United Nations Today. (8-14). Westview.

Barkin, Samuel, J. (2006). International Organization: Theories and Institutions. Palgrave Macmillan.

Bales, F. Eugene. (2008). Philosophy in the West: Men, Women, Religion, Science. Xlibris.

Burchill, Scott. (2005). Liberalism. In Burchill, Scott., Linklater, Andrew., Devetak, Richard., Donelly, Jack., Paterson, Matthew., Reus-Smit, Christian., \& True, Jacqui. (2005). Theories of International Relations. Palgrave Macmillan.

Dudley, R., Donald. (1937). A History of Cynicism; From Diogenes to the $6^{\text {th }}$ Century A.D. Methuen \& CO. LTD. London.

Flanagan, Owen. J. (1991). The Science of the Mind. Massachusetts Institute of Technology Press.

Newman, Edward., Thakur, Ramesh., \& Tirman, John. (Eds.). (2006). Multilateralism under challenge? Power, International Order, and structural change. United Nations University Press.

Wibisono, Makarim. (2006). Tantangan Diplomasi Multilateral (The Challenges of Multilateral Diplomacy). Pustaka LP3ES Indonesia

Journal Articles

Cook, Walter., \& Medley, Donald. (1954). Proposed Hostility and Pharisaic-Virtue Scales for the MMPI. Journal of Applied Psychology, 38.

Ikenberry, John, G. (2003). Is American Multilateralism in Decline?. Perspectives on Politics, 1(3), 533-550.

Kahler, Miles. (1992). Multilateralism with Small and Large Numbers. International Organization, 46(3), 681-708.

Kayupa, Irianto, Fiki., \& Muryantini, Sri. (2018). Kebijakan Gambia Keluar dari Mahkamah Internasional pada Era Pemerintahan Yahya Jammeh. Jurnal Studi Diplomasi dan Keamanan, 10(1), 27-49. 
Keohane, O., Robert. (1990). Multilateralism: An Agenda for Research. International Journal, (45)4, 731-764.

Linn, Johannes. (2018). Recent Threats to Multilateralism. Global Journal of Emerging Market Economies, 9(1-3), 86-113.

Stephanie, Tracy, Happy. (2018). The Smallness of Small States: Between Power and Vulnerability. Jurnal Studi Diplomasi dan Keamanan (Journal of Diplomatic Studies and Security), 10(2), 1-11.

Schutijser, Dennis. (2017). Cynicism as a way of life: From the Classical Cynic to a New Cynicism. Akropolis: Journal of Hellenic Studies, 1, 33-54.

Oshiba, Ryo. (2013). Multilateral diplomacy and multilateralism: The United Nations, the G8, the G20, and the Bretton Woods Institutions. The Japan Institute of International Affairs. 1-20.

Pattyn, Sven., Hiel, Van, Alain., Dhont, Kristof., \& Onraet, Emma. (2011). Stripping the Political Cynic: A Psychological Exploration of the Concept of Political Cynicism. European Journal of Personality.

Raustiala, Kal. (2000). Sovereignty and Multilateralism. Chicago Journal of International Law, (1)2, 401-419.

Ruggie, G. J. (1992). Multilateralism: The Anatomy of an Institution. International Organization, 46(3), 561-598.

Ruggie, G. J. (1994). Third Try at World Order? America and Multilateralism after the Cold War. Political Science Quarterly, 109(4), 553-570.

Schutijser, Dennis. (2017). Cynicism as a way of life: From the Classical Cynic to a New Cynicism. Akropolis: Journal of Hellenic Studies, 1, 33-54.

Sjolander, Turenne, Claire. (1996). The Rhetoric of Globalization: What is in a Wor(I)d?. International Journal: Canada's Journal of Global Policy Analysis, (51)4, 603-616.

Turner, H., James., \& Valentine, R., Sean. (2001). Cynicism as a Fundamental Dimension of Moral Decision-Making: A Scale Development. Journal of Business Ethics, 34, 123-136

\section{Commentaries}

Benner, Thorsten. (2019). We are witnessing the end of multilateralism. Global Public Policy Institute. Available at: https://www.gppi.net/2019/11/04/whatsleft-of-multilateralism-putting-six-hypotheses-to-the-test

Dervis, Kemal. (2018). Global power is shifting; Is it the end of multilateralism?. World Economic Forum. Available at: https://www.weforum.org/agenda/2018/07/is-this-the-end-of-multilateralism

Gowan, Richard. (2018). Multilateralism in Freefall?. United Nations University Centre for Policy Research. Available at: https://cpr.unu.edu/the-multilateralfreefall.html

Kingo, Lise., \& Mather, Scott. (2019). 3 things business leaders should do to make a renewed case for multilateralism. World Economic Forum. Available at: 
https://www.weforum.org/agenda/2019/04/3-things-business-leaders-shoulddo-to-make-a-renewed-case-for-multilateralism/

Nantulya, Paul. (2017). What's next for Africa and the International Criminal Court?. Africa Center for Strategic Studies. Available at: https://africacenter.org/spotlight/whats-next-africa-international-criminalcourt-icc/

Charbonneau, Louis. (2019, June 24). Multilateralism under threat. Humans Right Council. Available at: https://www.hrw.org/news/2019/06/24/multilateralism-under-threatReports

\section{$\underline{\text { Reports }}$}

Arms Trade Treaty. (2013). United Nations Treaty Collection. New York. Available at: $\quad$ https://treaties.un.org/doc/Publication/MTDSG/Volume II/Chapter XXVI/XXVI-8.en.pdf

Bacaria, Jordi. (2017). Populism and Its Impact on Multilateral Institutions and Economic Trade. CIDOB; Barcelona Centre for International Affairs. Available at: https://www.cidob.org/en/articulos/cidob report/n1 1/populism and its impa ct on multilateral institutions and economic trade

European Council. (2020, March 18). Climate change: what the EU is doing. Available at: https://www.consilium.europa.eu/en/policies/climate-change/

Friedrich, Johannes., Ge, Mengpin,. \& Andrew, Pickens. (2017, April 11). This Interactive Chart Explains World's Top 10 Emitters, and How They've Changed. World Resources Institute. Available at: https://www.wri.org/blog/2017/04/interactive-chart-explains-worlds-top-10emitters-and-how-theyve-changed

United Nations Climate Change. (n.d.). Paris Agreement - Status of Ratification. Available at: https://unfccc.int/process/the-paris-agreement/status-ofratification

Universities' Publication

Clark, Anthony. (2016). Classical Realism and Human Nature. Prized Writing, University of California, Davis. Available at: https://prizedwriting.ucdavis.edu/sites/prizedwriting.ucdavis.edu/files/users/mt rujil3/148PW\%20Clark.pdf

\section{Internet Sources}

Abramson, Jeff., \& Greg Webb. (2019, May). The U.S. to quit the Arms Trade Treaty. Arms Control Association. Available at: https://www.armscontrol.org/act/2019-05/news/us-quit-arms-trade-treaty

Army Technology. (2019, May 8). The top ten arms exporting countries in 2018. Available at: https://www.army-technology.com/features/arms-exports-bycountry/

Chakraborty, Barnini. (2017, June 1). Paris Agreement on climate change: the US withdraws as Trump calls it 'unfair'. Fox News. Available at: https://www.foxnews.com/politics/paris-agreement-on-climate-change-uswithdraws-as-trump-calls-it-unfair 
Chappell, Bill. (2019, April 26). Trump moves to withdraw U.S. from U.N. Arms Trade Treaty. NPR.

Available

at: https://www.npr.org/2019/04/26/717547741/trump-moves-to-withdraw-u-sfrom-u-n-arms-trade-treaty

Dictionary.com. (2020). Cynical. https://www.dictionary.com/browse/cynical

Easly, Jonathan. (2017, June 2). Trump cements 'America First' doctrine with Paris withdrawal. The Hill. Available at: https://thehill.com/homenews/administration/336014-trump-cementsamerica-first-doctrine-with-paris-withdrawal

Freedman, Rosa. (2015, July 7). How rights violators keep the UN Human Rights Council focused on Israel. The Conversation. Available at: https://theconversation.com/how-rights-violators-keep-the-un-human-rightscouncil-focused-on-israel-44319

Freedman, Rosa. (2018, June 20). Why the US left the UN Human Rights Council - and why it matters. The Conversation. Available at: https://theconversation.com/why-the-us-left-the-un-human-rights-counciland-why-it-matters-98644

Gumede, William. (2018, January 31). The International Criminal Court and Accountability in Africa. Wits School of Governance News. Available at: https://www.wits.ac.za/news/sources/wsg-news/2018/the-internationalcriminal-court-and-accountability-in-africa.html

Gurria, Angel. (2018, June 04). Multilateralism is the only way forward. Inquirer.net. Available at: https://opinion.inquirer.net/113668/multilateralismway-forward

Igunza, Emmanuel. (2017, February 1). African Union backs mass withdrawal from ICC. BBC News. Available at: https://www.bbc.co.uk/news/world-africa$\underline{38826073}$

Iran nuclear deal: Key details. (2019, June 11). BBC News. Available at: https://www.bbc.com/news/world-middle-east-33521655

Iran to restart some nuclear activity in response to U.S. withdrawal from nuclear deal. (2019, May 6). Reuters. Available at: https://www.reuters.com/article/ususa-iran-actions/iran-to-restart-some-nuclear-activity-in-response-to-uswithdrawal-from-nuclear-deal-idUSKCN1SC1FP

Jarvi, Gamble, Gwenyth. (2017, February 1). African Union leaders back leaving ICC. Jurist. Available at: https://www.jurist.org/news/2017/02/african-unionleaders-back-leaving-icc/

Landler, Mark. (2018, May 8). Trump abandons Iran Nuclear Deal he long scorned. The New York Times. Retrieved from https://www.nytimes.com/2018/05/08/world/middleeast/trump-iran-nucleardeal.html

Mesele, Z., Abreha. (2019, June 17). International Criminal Court and the African Union: Selective Justice?. Abyssinia Law. Available at: https://www.abyssinialaw.com/blog-posts/item/1513-international-criminalcourt-and-african-union-selective-justice 
Piering, Julie. (n.d.). Cynics. Internet Encyclopedia of Philosophy. Available at: https://www.iep.utm.edu/cynics/

Presse-France, Agence. (2017, October 27). Burundi becomes the first nation to leave the International Criminal Court. The Guardian. Available at: https://www.theguardian.com/law/2017/oct/28/burundi-becomes-first-nationto-leave-international-criminal-court

The Wire. (2016, November 11). Iran Has Options if Parties Don't Stick to International Nuclear Deal. Available at: https://thewire.in/world/iran-hasoptions-if-parties-dont-stick-to-international-nuclear-deal

Torbati, Yeganeh. (2016, November 9). Trump election puts Iran nuclear deal on shaky ground. Reuters. Available at: https://www.reuters.com/article/us-usaelection-trump-iran/trump-election-puts-iran-nuclear-deal-on-shaky-groundidUSKBN13427E

UN votes to send war crimes investigators to Gaza. (2018, May 18). Aljazeera. Available at: https://www.aljazeera.com/amp/news/2018/05/votes-send-warcrimes-investigators-gaza-180518142752946.html

US withdraws from the UN Human Rights Council. (2018, June 20). Aljazeera. Available at: https://www.aljazeera.com/news/2018/06/withdraws-humanrights-council-180619173311272.html

Wolfe, Lauren. (2018, June 20). Trump's Insidious Reason for Leaving the UN Human Rights Council. The Atlantic. Available at: https://www.theatlantic.com/international/archive/2018/06/trump-haley-unhuman-rights-israel-venezuela-withdrawal/563246/

Wolffe, Richard. (2017, June 2). Trump asked when the world will start laughing at the US. It already is. The Guardian. Available at: https://www.theguardian.com/commentisfree/2017/jun/02/trump-worldlaughing-at-us-paris-climate-deal

Multilateralism is under fire when the world needs it most: UN chief. (2018, September 26). China Daily. Available at: http://www.chinadaily.com.cn/a/201809/26/WS5baae468a310c4cc775e81ce.h $\underline{\mathrm{tml}}$ 


\section{Working Papers}

Krueger, O. Anne. (2011). The Importance of Multilateralism in the Twenty-First Century. Stanford Center for International Development, Working Paper 450. Available

at:

https://kingcenter.stanford.edu/sites/default/files/publications/450wp.pdf

Moreland, Will. (2019). The Purpose of Multilateralism; A Framework for Democracies in a Geopolitically Competitive World. The Brooking Institution. Available at: https://www.brookings.edu/wpcontent/uploads/2019/09/FP 20190923 purpose of multilateralism moreland. pdf 